\title{
Short Communication: A Positive Relationship Between the First Ovulation Postpartum and the Increasing Ratio of Milk Yield in the First Part of Lactation in Dairy Cows
}

\author{
C. Kawashima, ${ }^{*}$ C. Amaya Montoya,† Y. Masuda,\# E. Kaneko, ${ }^{*}$ M. Matsui,† T. Shimizu, ${ }^{*}$ \\ N. Matsunaga,ł K. Kida,§ Y.-I. Miyake,† M. Suzuki,|| and A. Miyamoto*1 \\ *Graduate School of Animal and Food Hygiene, \\ †Department of Clinical Veterinary Science, \\ ‡Department of Agricultural and Life Science, \\ $\S$ Field Center of Animal Science and Agriculture, and \\ |Department of Food Production Science, Obihiro University of Agriculture and Veterinary Medicine, Obihiro 080-8555, Japan \\ \#The United Graduate School of Agricultural Sciences, Iwate University, Morioka 020-8550, Japan
}

\begin{abstract}
The aim of the present study was to examine the relationship between characteristics of the lactation curve, on the basis of daily milk yield, and ovulation within 3 wk postpartum as an indicator of early return to luteal activity in dairy cows. Lactation records from 46 lactating Holstein cows between calving and $305 \mathrm{~d}$ postpartum were studied. Milk samples were collected twice weekly between $\mathrm{d} 7$ and 100 for later determination of progesterone concentrations. Occurrence of an early first ovulation was determined by an increase in milk progesterone by $3 \mathrm{wk}$ after calving. Milk yield was recorded daily until $305 \mathrm{~d}$ postpartum, and average yield was calculated weekly. The lactation curve was characterized by 8 indices on the basis of the weekly average of milk yield as follows: a) first-week milk yield; b) peak milk yield; c) actual 305-d milk yield; d) peak week; e) difference in milk yield between the first week and peak week; f) difference in milk yield between the peak week and last week (43rd week postpartum); g) ratio of increase in milk yield between wh 1 and the week of peak yield; and $\mathrm{h}$ ) ratio of decline in milk yield between the week of peak yield and the last week. Indices $g$ and $h$ were calculated as linear. The number of cows having ovulated by 3 wk postpartum was 22 (47.8\%). The resumption of ovarian cycles with normal luteal phases occurred earlier in ovular cows than in anovular cows (32.0 d vs. $57.1 \mathrm{~d}$ ). Although total milk yield did not differ between ovular and anovular cows, the ratio of increase in milk yield from the first week to the peak week (index g) in ovular cows was smaller compared with that of anovular cows (1.71 vs. 2.54$)$. In
\end{abstract}

Received July 3, 2006.

Accepted November 15, 2006.

${ }^{1}$ Corresponding author: akiomiya@obihiro.ac.jp addition, the ratio of increase in milk yield from the first week to the third week postpartum was greater in anovular cows by $3 \mathrm{wk}$ postpartum (ovular $=1.43 \pm$ 0.23 vs. anovular $=2.32 \pm 0.29$ ). In conclusion, the present study demonstrates that a greater increasing ratio of milk yield during early lactation may delay resumption of ovarian cycles after parturition. Therefore, this study is the first to demonstrate statistically that a smaller increasing ratio of milk yield (index g) during early lactation may have a beneficial effect on the first ovulation by 3 wk postpartum.

Key words: lactation curve characteristic, dairy cow, first ovulation postpartum

During the past decades, milk production per cow has increased drastically because of improved management, nutrition, and genetic selection (Hansen, 2000; Lucy, 2001), but the reproductive performance of highproducing dairy cows has declined (Butler, 1998; Lucy, 2001; Washburn et al., 2002). One of the contributing factors to this low reproductive performance is a negative energy balance, which is characterized by the loss of BW and mobilization of body fat after parturition. Negative energy balance affects the onset of first ovulation in early postpartum cows (Beam and Butler, 1999; Lucy, 2001). However, the relationship between milk yield and the resumption of postpartum ovarian function remains unclear. In most dairy cows, medium-sized follicles appear by $5 \mathrm{~d}$ after calving and large follicles appear by $10 \mathrm{~d}$ postpartum (Savio et al., 1990a,b). Approximately half of all cows ovulate by $3 \mathrm{wk}$ postpartum (Lamming and Bulman, 1976; Lucy et al., 1992; Darwash et al., 1997). Although one study demonstrated that ovulation by 3 wk postpartum may have negative effects on subsequent ovarian function and the conception rate (Smith and Wallace, 1998), our recent study indicated that resumption of normal ovarian function 
and subsequent reproductive performance was earlier in ovular cows by $3 \mathrm{wk}$ postpartum than in anovular cows (Kawashima et al., 2006). The aim of the present study was to examine the relationship between characteristics of the lactation curve, on the basis of daily milk yield, and the interval to postpartum ovulation in dairy cows.

Forty-six multiparous Holstein cows, which calved between May 2001 and December 2003, were milked for more than $305 \mathrm{~d}$. Milk samples were collected twice weekly after milking between 7 and 100 DIM. After centrifugation at $2,000 \times g$ for $45 \mathrm{~min}$ at $4^{\circ} \mathrm{C}$, the fat layer was removed and the remaining skim milk samples were stored at $-30^{\circ} \mathrm{C}$ until analysis for progesterone concentration. Determination of progesterone in skim milk was performed by enzyme immunoassay after extraction by diethyl ether as described previously (Miyamoto et al., 1992). The extraction efficiency was $88 \%$. When the progesterone concentration in the skim milk first exceeded $1 \mathrm{ng} / \mathrm{mL}$, luteal activity was assumed to have been initiated (Stevenson and Britt, 1979). Cows having resumed luteal activity by $3 \mathrm{wk}$ postpartum were defined as having ovulated (ovular), whereas those not having resumed luteal activity by 3 wk were defined as anovular. In addition, a normal luteal phase was indicated when progesterone concentrations remained $>1 \mathrm{ng} / \mathrm{mL}$ for more than $7 \mathrm{~d}$ (more than 3 samples) and at least 2 of the 3 sample concentrations were $>2 \mathrm{ng} / \mathrm{mL}$. Detection of 2 consecutive normal luteal phases was regarded as the resumption of normal ovarian cycles.

Milk yield was recorded daily until 305 DIM and milk yield was averaged weekly. The lactation curve was characterized by 8 indices on the basis of the weekly average of milk yield as follows: a) first-week milk yield; b) peak milk yield; c) actual 305-d milk yield; d) peak week; e) difference in milk yield between the first week and the peak week; f) difference in milk yield between the peak week and the last week (43rd week postpartum); g) ratio of increase in milk yield between wk 1 and the week of peak yield; and h) ratio of decline in milk yield between the week of peak yield and the last week (Figure 1). We calculated the linearity of indices $\mathrm{g}$ and $\mathrm{h}$ as follows:

$$
\begin{gathered}
\mathrm{g}=(\mathrm{MYp}-\mathrm{MYf}) / \mathrm{PW} \\
\text { and } \mathrm{h}=(\mathrm{MYp}-\mathrm{MYl}) /(\mathrm{LW}-\mathrm{PW}),
\end{gathered}
$$

where MYf is the first week milk yield, MYp is the peak week milk yield, MYl is the last week milk yield, PW is the peak week, and LW is the last week.

The relationship between characteristics of the lactation curve and occurrence of the first ovulation by 3

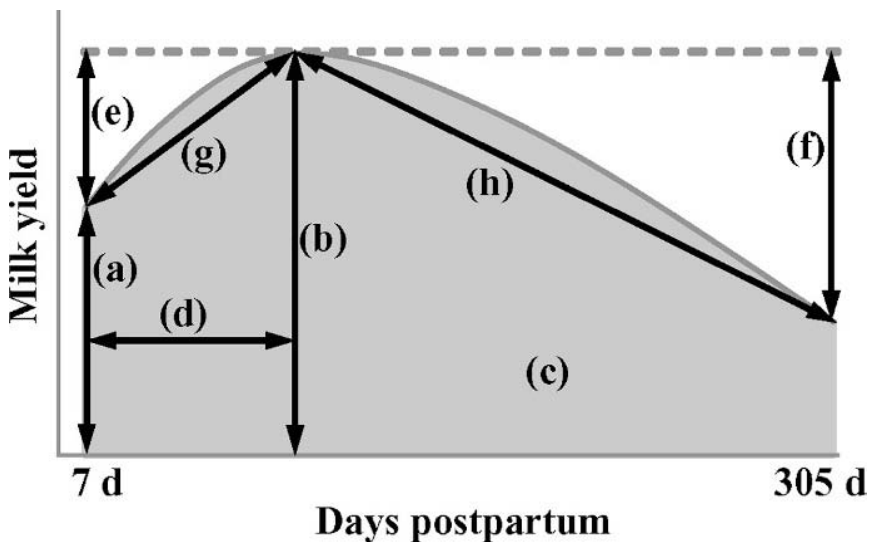

Figure 1. The lactation curve was characterized by 8 indices on the basis of the weekly average of milk yield: a) first-week milk yield; b) peak milk yield; c) actual 305-d milk yield; d) peak week; e) difference in milk yield between the first week and the peak week; f) difference in milk yield between the peak week and the last week (43rd week postpartum); g) ratio of increase in milk yield between wk 1 and the week of peak yield; and h) ratio of decline in milk yield between the week of peak yield and the last week.

wk postpartum was analyzed by using Student's $t$-test, where indices of the lactation curve were compared between ovular and anovular cows. Spearman's rank correlation was applied to determine relationships among other factors, such as season of calving, age, diagnosis of peripartum disease, and occurrence of ovulation by 3 wk postpartum. Results were expressed as mean \pm standard error of the mean.

In the present study, incidence of first ovulation by 3 wk postpartum was observed in 22 of 46 cows ( $47.8 \%$ ). No interaction was detected between season of calving $(P=0.40)$, age of cow $(P=0.80)$, diagnosis of peripartum disease [ovular $(\mathrm{n}=7)$; anovular $(\mathrm{n}=10) ; P=0.50$ ], and ovulation of the dominant follicle of the first postpartum follicular wave. This result is consistent with previous data in which early luteal activity by 3 wk postpartum was observed in half of the cows (Smith and Wallace, 1998; Kawashima et al., 2006). Days to the resumption of normal ovarian cycles were less $(P<0.001)$ in ovular and anovular cows (Table 1). Our results indicate that

Table 1. Number of cows that ovulated by 3 wk postpartum and initiation of ovarian cycles

\begin{tabular}{llll}
\hline & \multicolumn{2}{c}{ Ovarian status by } \\
& \multicolumn{2}{c}{ 3 wk postpartum } & \\
\cline { 2 - 3 } Item & Ovular & Anovular & $P$ \\
\hline No. of cows $(\%)$ & $22(47.8)$ & $24(52.2)$ & - \\
Initiation of ovarian cycles, ${ }^{1} \mathrm{~d}$ & $32.0 \pm 4.6$ & $57.1 \pm 4.8$ & *** \\
\hline
\end{tabular}

\footnotetext{
${ }^{1}$ Mean $\pm \mathrm{SE}$.
}

$* * * P<0.001$ 
Table 2. Indices of lactation curve in ovular or anovular cows within 3 wk postpartum

\begin{tabular}{|c|c|c|c|}
\hline \multirow[b]{2}{*}{ Item $^{1}$} & \multicolumn{2}{|c|}{ Ovarian status by $3 \mathrm{wk}$ postpartum ${ }^{2}$} & \multirow[b]{2}{*}{$P$} \\
\hline & Ovular & Anovular & \\
\hline First week milk yield (a), kg & $37.1 \pm 1.1$ & $35.9 \pm 1.4$ & - \\
\hline Peak milk yield (b), kg & $44.1 \pm 1.1$ & $44.9 \pm 1.4$ & - \\
\hline Actual 305-d milk yield (c), kg & $10,079 \pm 223$ & $10,277 \pm 286$ & - \\
\hline Peak milk week (d), wk & $6.3 \pm 0.8$ & $5.0 \pm 0.5$ & - \\
\hline Difference $(e=a-b), k g$ & $7.0 \pm 0.6$ & $9.0 \pm 1.0$ & - \\
\hline Difference in peak week and 1 wk before $305 \mathrm{~d}$ (f), $\mathrm{kg}$ & $20.9 \pm 1.2$ & $19.8 \pm 1.6$ & - \\
\hline $\begin{array}{l}\text { Ratio of increase in yield between wk } 1 \text { and week of } \\
\text { peak }(\mathrm{g})\end{array}$ & $1.71 \pm 0.2$ & $2.54 \pm 0.2$ & * \\
\hline $\begin{array}{l}\text { Ratio of decrease between week of peak and week } \\
\text { before } 305 \mathrm{~d}(\mathrm{~h})\end{array}$ & $-0.62 \pm 0.04$ & $-0.57 \pm 0.04$ & - \\
\hline
\end{tabular}

${ }^{1}$ Characteristics of the lactation curve were classified by 8 indices (letters a to h; see Figure 1) on the basis of weekly average milk yield.

${ }^{2}$ Mean $\pm \mathrm{SE}$.

$* P<0.05$.

milk yield peaked at approximately $44 \mathrm{~kg}$ between the fifth and sixth week postpartum in both ovular and anovular cows (Table 2). Although most of the lactation indexes in this study did not differ between ovular and anovular cows, the ratio of increase in milk yield between the first week postpartum and the week of peak yield (index g) in anovular cows was greater $(P<0.05)$ than in ovular cows (Table 2), despite having similar total lactation yields. In addition, the ratio of increase in milk yield between the first and third week postpartum was greater $(P<0.05)$ in anovular cows than in ovular cows (Table 2). A previous study showed that negative energy balance was directly related to the postpartum interval to first ovulation, and that differences in energy balance were reflected in the milk yield (Butler and Smith, 1989). In contrast, another study showed that cows having delayed resumption of luteal activity had greater negative energy balance between the first and second week postpartum compared with cows having resumed early luteal activity, despite not differing in milk yield (Staples et al., 1990). Therefore, negative energy status is not always affected by milk yield but relates to the resumption of estrous cycles, and this view supports our suggestion that the energy status in anovular cows might be worse than in ovular cows despite having similar milk yields.

Negative energy balance usually reaches its nadir during the first or second week postpartum (Butler and Smith, 1989). We hypothesize that the relationship between energy status and the increasing ratio of milk yield during early lactation (index g), despite having similar first-week and peak milk yields, may be associated with anovulation before 3 wk postpartum. Energy balance is affected not only by milk yield but also by energy intake and mobilization of body fat stores, and ovarian activity is influenced by energy status (Staples et al., 1990). Although energy balance was not assessed in our study, the ratio of increased milk yield in anovular cows may have induced greater negative energy balance during early lactation compared with ovular cows. Further studies are necessary to investigate the relationship between energy balance and the ratio of increase in milk yield during early lactation. Because early first ovulation is positively related to the resumption of normal ovarian function, first service, and conception in dairy cows (Senatore et al., 1996; Darwash et al., 1997; Kawashima et al., 2006), nutritional management aimed at increasing DMI or producing a smaller increase in milk yield in early lactation may result in shorter postpartum anovulation.

In conclusion, we provide the first statistical demonstration that the greater increasing ratio of milk yield during early lactation may have affected the occurrence of late first ovulation after parturition, and propose using the lactation curve as a simple model to evaluate the physiological environment for resumption of normal ovarian cycles in postpartum cows.

\section{ACKNOWLEDGMENTS}

The authors thank K. Okuda, Okayama University, Japan, for the progesterone antiserum. This study was supported by a Grant-in-Aid for Scientific Research from the Japan Society for the Promotion of Science (JSPS) and by the 21st Century COE Program (A-1) of the Ministry of Education, Culture, Sports, Science and Technology of Japan; the Secure and Healthy Livestock Farming Project of the Ministry of Agriculture, Forestry and Fisheries of Japan; and the Japan Livestock Technology Association. C. Kawashima and E. Kaneko were supported by the COE Program.

\section{REFERENCES}

Beam, S. W., and W. R. Butler. 1999. Effects of energy balance on follicular development and first ovulation in postpartum dairy cows. J. Reprod. Fertil. Suppl. 54:411-424. 
Butler, W. R. 1998. Review: Effect of protein nutrition on ovarian and uterine physiology in dairy cattle. J. Dairy Sci. 81:2533-2539.

Butler, W. R., and R. D. Smith. 1989. Interrelationships between energy balance and postpartum reproductive function in dairy cattle. J. Dairy Sci. 72:767-783.

Darwash, A. O., G. E. Lamming, and J. A. Woolliams. 1997. The phenotypic association between the interval to post-partum ovulation and traditional measures of fertility in dairy cattle. Anim. Sci. 65:9-16.

Hansen, L. B. 2000. Consequences of selection for milk yield from a geneticist's viewpoint. J. Dairy Sci. 83:1145-1150.

Kawashima, C., E. Kaneko, C. Amaya Montoya, M. Matsui, N. Yamagishi, N. Matsunaga, M. Ishii, K. Kida, Y. Miyake, and A. Miyamoto. 2006. Relationship between the first ovulation within three weeks postpartum and subsequent ovarian cycles and fertility in high producing dairy cows. J. Reprod. Dev. 52:479-486.

Lamming, G. E., and D. C. Bulman. 1976. The use of milk progesterone radioimmunoassay in the diagnosis and treatment of subfertility in dairy cows. Br. Vet. J. 132:507-517.

Lucy, M. C. 2001. Reproductive loss in high-producing dairy cattle: Where will it end? J. Dairy Sci. 84:1277-1293.

Lucy, M. C., C. R. Staples, W. W. Thatcher, P. S. Erickson, R. M. Cleale, J. L. Firkins, J. H. Clark, M. R. Murphy, and B. O. Brodie. 1992. Influence of diet composition, dry matter intake, milk production and fertility in dairy cows. Anim. Prod. 54:323-331.

Miyamoto, A., K. Okuda, F. J. Schweigert, and D. Schams. 1992 Effects of basic fibroblast growth factor, transforming growth factor- $\beta$ and nerve growth factor on the secretory function of the bovine corpus luteum in vitro. J. Endocrinol. 135:103-114.

Savio, J. D., M. P. Boland, and J. F. Roche. 1990a. Development of dominant follicles and length of ovarian cycles in post-partum dairy cows. J. Reprod. Fertil. 88:581-591.

Savio, J. D., M. P. Boland, N. Hynes, and J. F. Roche. 1990b. Resumption of follicular activity in the early post-partum period of dairy cows. J. Reprod. Fertil. 88:569-579.

Senatore, E. M., W. R. Butler, and P. A. Oltenacu. 1996. Relationship between energy balance and postpartum ovarian activity and fertility in first lactation dairy cows. Anim. Sci. 62:17-23.

Smith, M. C. A., and J. M. Wallace. 1998. Influence of early post partum ovulation on the re-establishment of pregnancy in multiparous and primiparous cows. J. Reprod. Fertil. Dev. 10:207-216.

Staples, C. R., W. W. Thatcher, and J. R. Clark. 1990. Relationship between ovarian activity and energy status during the early postpartum period of high producing dairy cows. J. Dairy Sci. 73:938-947.

Stevenson, J. S., and J. H. Britt. 1979. Relationships among luteinizing hormone, estradiol, progesterone, glucocorticoids, milk yield, body weight, and postpartum ovarian activity in Holstein cows. J. Anim. Sci. 48:570-577.

Washburn, S. P., W. J. Silvia, C. H. Brown, B. T. McDaniel, and A. J. McAllister. 2002. Trends in reproductive performance in Southeastern Holstein and Jersey DHI herds. J. Dairy Sci. $85: 244-251$ 